Departamento de Historia Universidad de Santiago de Chile

Revista de Historia Social

y de las Mentalidades

Volumen 24, $\mathrm{N}^{\circ} 2,2020: 1-40$

Issn Online: 0719-4749

\title{
PRAEDICATIO EST: HUMBERT OF ROMANS, JACOBUS OF FUSIGNANO AND GIORDANO DA PISA ON THE PREACHING OF THE ORDER OF THE FRIAR PREACHERS IN THE LATE 13TH AND EARLY 14TH CENTURIES*
}

\author{
PRAEDICATIO EST: HUMBERTO DE ROMANS, JACOBUS DE FUSIGNANO E GIORDANO \\ DE PISA SOBRE LA ACTIVIDAD PREDICATIVA DE LA ORDEN DE LOS FRAILES \\ PREDICADORES EN LA SEGUNDA MITAD DEL SIGLO XIII Y PRINCIPIOS DEL XIV
}

\author{
DR. ALÉSSIO ALONSO ALVES** \\ Universidade Federal de Minas Gerais \\ Belo Horizonte, Brazil \\ Email: alessioalonso@ufmg.br/alessioaalves@gmail.com \\ Id-ORCID: 0000-0001-9634-792x
}

\begin{abstract}
RESUMEN
El propósito de este artículo es establecer un concepto sintético de predicación de acuerdo con las declaraciones expresadas por tres frailes predicadores en la segunda mitad del siglo XIII y principios del siglo XIV. Partiendo de la definición ofrecida por el teólogo Alain de Lille (1128-1202),

hoy tomada como paradigmática, se analizan y comparan tres obras de diferentes naturalezas: $D e$ eruditione religiosorum praedicatorum (1263) de Humberto de Romans (1190-1277); Libellus artis

ABSTRACT

The purpose of this article is to establish a synthetic concept of preaching according to the statements expressed by three Friars Preachers in the second half of the thirteenth and early fourteenth century. Starting with the definition by the theologian Alain de Lille (1128-1202), today taken as paradigmatic, three works of different natures are analyzed and compared: De eruditione religiosorum praedicatorum (1263), by Humbert of Romans (1190-1277); the Libellus artis predicatorie

* $\quad$ Recibido: 11 de abril de 2020; Aprobado: 6 de noviembre de 2020.

** Scientific Article. This article comes from my PhD research (concluded) entitled A Pregação e a Comunidade: reflexões morais e sobre a origem e configuração da sociedade humana nos sermões de Giordano de Pisa, O.P. (1302-1309), supported by Coordenação de Aperfeiçoamento de Pessoal de Nível Superior (CAPES) within the Ministry of Education, Brazil, and developed in the Graduate Program in History, Faculdade de Filosofia e Ciências Humanas (FAFICH), of the Universidade Federal de Minas Gerais (UFMG), Brazil.
\end{abstract}


predicatorie (1290), de Jacobus de Fusignano (? -1333); y las reportationes de dos sermones (1304) de Giordano de Pisa (c. 1260-1311). Como conclusión, la predicación se sintetiza en un concepto como instrucción sobre las Sagradas Escrituras, la fe y la verdad; sobre moral, vicios y pecados, cuyo fin es la salvación.

Palabras clave: Predicación; frailes predicadores; Orden dominicana; sermón
(1290), by Jacobus of Fusignano (? -1333); and the reportationes of two sermons (1304) by Giordano da Pisa (c. 1260-1311). As a conclusion, preaching is synthesized into a concept as an instruction on the Holy Scriptures, divine things, faith, and truth; as well as about morals, vices and sins, whose goal is the salvation of its audience.

Keywords: Preaching; Friars Preachers;

Dominican Order; Sermon

\section{INTRODUCTION}

In the seminal collaborative work entitled The Sermon -"a touchstone for the field [of medieval sermon studies]" published in the year 2000 (Thayer 10), its director, the renowned American scholar Beverly Mayne Kienzle, began its introduction defining the the genre as follows:

The sermon represented the central literary genre in the lives of European Christians and Jews during the Middle Ages. It provided the primary medium for Christian clergy to convey religious education to lay audiences, and it played an important role in the liturgy and life of the religious orders (...) an essentially oral and highly performative genre (Kienzle 143, emphasis added).

Important not only to the Christian society, but also to the Jewish community, from this appreciation, it stands out -in addition to its participation in the liturgy ${ }^{1}$ and in the daily life of religious orders- first the educational function of the sermon in terms of Christian religious doctrine. Its main goal, as made clear by Carlo Delcorno in his contribution to the publication, was the manifestatio of the biblical text ("Medieval" 449, 451, 457). As such, the sermon was a mean for this instruction and, precisely for this reason, it is considered as one of the ways by which form, and meaning were infused into a Christian community.

Later on, Kienzle refined this definition and presented it as follows: "1) the sermon is essentially an oral discourse, spoken in the voice of a preacher who

$1 \quad$ For the relationship between sermon, preaching, liturgy and research methods, see Alves; Anderson; Bériou and Morenzoni; D'Avray, "Method"; and Hanska, "Reconstructing" and "Uidens". 
addresses an audience, 2) to instruct and exhort them, 3) on a topic concerned with faith and morals and based on a sacred text" (Kienzle 151). ${ }^{2}$ Although her description is very accurate as it regards the third point (as will be evident along this article), all in all this definition is somewhat problematic, especially in its first and second statements.

As Jussi Hanska affirmed in his chapter in The Sermon, besides the oral speech itself (including performative features such as the preacher's gestures, body expressions and voice intonations), ${ }^{3}$ a sermon could be at the same time either a previously written text from which the preacher conducted his oral performance (preaching) and its reportatio, that is, the written record of his oral discourse made by someone in the audience (Hanska, "Reconstructing" 296). ${ }^{4}$ In fact, when discussing this first point Kienzle herself recognized the narrowness of her statement and added "an audience of readers" as the receptor of the sermon, thus acknowledging it also as a written discourse $(151,159)$. Likewise, in a more radical sense, according to George Ferzoco on the hermit saints and preachers, the lives of these men were worth more than their speech (or any written texts), so they did not need an oral (or written) sermon to preach. Consequently, the transmission of messages and teachings was not necessarily an auricular event (Ferzoco 158). ${ }^{5}$ Thus, considering all these difficulties, Kienzle recognized that

According to Anne T. Thayer (11), "much subsequent scholarship on medieval sermons has quoted this definition".

3 In this regard, see Berardini; Palermo; Swan; Thompson, "From Texts".

$4 \quad$ Pietro Delcorno (In the mirror 150) says that "Although preaching was a singular event in which there was an actual interaction between preacher and audience it remains something that we cannot recover completely, just as any other form of performance, it is possible to approach it using so-called reportationes". However, it is necessary to bear in mind, as literary historian Carlo Delcorno ("Medieval" 497) rightly points out, that "the process of simultaneous transmission and reception of the word is forever lost even when we possess a reportatio". In his turn, as for the verbal discourse itself and the historian's possibilities to access what was in fact commonly said or, in effect, what was preached by a preacher, Hanska ("Reconstructing" 296) observes: "The actual sermons are beyond the reach of historical research because medieval technology did not allow for the exact recording of sermons as they were delivered. Therefore, we have to try to reconstruct what they were like. Some information can be gained from chronicles and other narrative sources that describe preachers at work (...) Nevertheless, our knowledge of the heart and essence of medieval Sunday sermons, that is, what was actually preached, comes from the surviving sermon texts. These can be divided into two categories: reportationes and model sermons". On the active role of the copyists as authors, see Stoop.

5 A reference to this form of preaching, in which the sermon is the preacher's or saints' own form of life, can be found at least in one of the reportationes of the preaching of friar Giordano da Pisa. Speaking in Florence's cathedral church Santa Maria Novellla on 28 August 1304, Saint Augustine's day, Friday morning, the friar presented the public with some reasons why the saints could, with justice, be compared to a very strong column that sustains the world. The third of 
"the definition of [the sermon as a] genre must modify accordingly to include categories of written and/or oral works" (Kienzle 145) -and even forms of life. In agreement with these observations on the sermon's possible multiple forms, in a subsequent publication entitled Preacher, Sermon and Audience in the Middle Ages (2002), the historian Carolyn Muessig drew attention to the fact that there cannot be a direct answer to the question what is a sermon? ${ }^{6}$ precisely because they were presented in many styles and genres (Preacher, 3) -thus varying specially in their structure with greater or lesser intensity. All this indicates that an approach deeply concerned with the sermon's forms might not be the most suitable way to establish a synthetic concept of it.

Regarding the second argument of Kienzle's definition, one may point out its lack of clarity. This is made evident by the need to explain it and discuss it. Although the educational function of the sermon is widely identified and accepted by scholars today, the formula "to instruct and exhort" does not make it immediately clear that the sermon "is concerned with the end of time and the listeners' salvation" (Kienzle 155). If this is really the main purpose and core of the sermon, this feature must be manifested in its characterization; it cannot be left to be understood implicitly.

Finally, Kinzle's definition is very accurate in stating that the public's instruction and exhortation (for the salvation of their souls) was made through the treatment of topics related to faith and morals, according to a text considered sacred. Thus, considering all these characteristics and difficulties in analyzing the sermon as a genre, a functional approach which "deals with the desired effect [of the sermon]" (Kienzle 146) seems to be a more suitable way to establish

these reasons would be edification: "The third thing for what the holy man is said to be a very strong column that strongly supports the world is propter aedificationem, by the example of his holy life to others. Oh, how big this column is! Brave column! How much use and how much edification does a holy man make to his neighbor by the example of his good life cannot be said. And their lives are like a preaching and a hammer to sinners" ["La terza cosa perché il santo uomo è detto colonna fortissima, che sostiene forte il mono, si è, propter aedificationem, per l'esemplo della sua santa vita al rossimo. Oh come questa è grande colonna! Mirabile colonna è. Quanta utilità, e quanta edificazione fa un santo uomo al prossimo per l'esemplo della sua buona vita, non si potrebbe dire; e come è una predica, ed uno martello a 'peccatori la sua vita"] (Giordano, Prediche del beato fra II 11). According to this passage, preaching would not even need words. A holy life, with holy attitudes, would have the same effects as the preacher's speech -if not greater. Preaching in deeds is also pointed by the theologian Alain de Lille, as will be shown later on this article.

6 According to Thayer (10), "at that time [of the publication of The Sermon], recognizing the fluidity of the genre and the range of meanings assigned to the word sermo, a central question in the field seemed to be: What is a sermon?". 
a concept of sermon and preaching. ${ }^{7}$ And it will be adopted in this article as it investigates the written productions of the time here in consideration and searches for definitions that help better understand how the friars Preachers of the late thirteenth and early fourteenth centuries who dedicated themselves to sermon and preaching understood their own occupation. Through this approach of the source material (Kienzle 146, 155), comparing all the definitions and comments on this activity and presenting their similarities and differences, this article seeks to clarify what were the sermon's main purpose and by which means it was achieved, thus providing a synthetic and operational concept of preaching.

\section{ALAIN DE LILLE'S SUMMA DE ARTE PRAEDICATORIA}

As Carolyn Muessig (Preacher 3-4) and Cecilia Iannella ("Predicazione" 171) point out, many scholars nowadays take the definition of preaching offered in the late twelfth century by the theologian Alain de Lille (1128-1202) as paradigmatic-especially in studies on the activities of the mendicant friars, despite the fact that Alain died before their arising. The reason for this lies in the fact that his Ars praedicandi $i^{8}$ was the first one to present some composition precepts concerning the sermon's form, which over the next century came to be known as the modern sermon (Wenzel, Medieval 4-5; Rivers 152), widely employed by both Friars Preachers and Minor. ${ }^{9}$ According to the literary historian Siegfried Wenzel,

(...) it contains a brief section on forma praedicationis, which includes such aspects of scholastic sermon technique as the use of a proper thema,${ }^{10}$ here called auctoritas, which forms the fundamentum of a sermon; a captatio benevolentiae; exposition of the authority, with

7 Indeed, Muessig stated that "the study [edited by her] examines the role of sermons and the function of preaching in Western Europe between the tenth and fifteenth centuries" and "presents us with a clearer comprehension of the role and significance of the sermon in the Middle Ages" (Preacher 3, 8, emphasis added).

8 A rhetorical treatise on how to compose a sermon according to the norms practiced at the time.

9 According to Siegfried Wenzel, prior to the Alain's work, it is possible to list the Liber quo ordine sermo fieri debaet of the Benedictine monk Guibert of Nogent (1055-1124). However, as the author points out, "despite its title the treatise does not deal with the structure of the public sermon but is an exhortation to preach, both orally and evidently in writing, for the moral benefit of others, emphasizing the need to discuss vices (for greater self-knowledge) and to understand Scripture in its four senses" (Wenzel, Medieval 4).

10 The gospel verse that serves as the basis for the preaching discourse, chosen from the Gospel reading of the day's liturgy. 
the use of other authorities including the sayings of gentiles; and proving one's points with exempla (...) illustrative chapters contain such techniques as division, distinction, confirmation, proof, and development including emotive language, address of the audience, quotations from [pagan] poets, etc (Wenzel, Medieval 5).

Entitled Summa de arte praedicatoria (c. 1170), Alain's work was produced in a context of strengthening of preaching's quality and universalization of its standards in the Western Christendom, a long process that started in the twelfth century and extended itself throughout the thirtheenth (Bériou, L'avènement 15; "Un mode" 113-114). This broad endeavor was conducted by both regular and secular ecclesiastics and had in Paris (where Alain studied and teached during the second half of the twelfth century), together with Laon and Lincoln, one of its main centers for the formation of preachers,as well as for the production of treaties on this activity.

In Alain's tract, preaching was defined as a "manifest and public instruction on customs and faith, information dedicated to men from the rational path and coming from the sources of the authorities" (Alanus col. 111). ${ }^{11}$ According to this definition -that was "echoed by latter composers of the artes praedicandi" (Kienzle 161) and that surely directed Kienzle's aforementioned characterizations-, when taken by the clergy, preaching constituted the main instrument of instruction and diffusion of catechetical and moral contents. Moreover, it is possible to identify in it the meeting point between theological, literary, scientific knowledge and everyday life (Delcorno, "Medieval" 450). Therefore, preaching and sermon would both be a discourse of the preacher that turns itself to an audience to instruct it on topics of faith and morals, based on sacred texts (Kienzle 151; Thayer 11). Preaching should also be visible and reach a large number of people, because it had to be evident and public:

Preaching must be manifest, for in public it is proposed. If preaching occurs occultly, it is suspect and we will see it smelling of heretical dogma (...) It must be public, for it is not proposed to one but to many. If it is proposed to only one, it is not preaching, but class (...) Preaching, then, is that instruction of many in manifest and for the instruction of customs (Alanus col. 111-112). ${ }^{12}$

11 "Praedicatio est, manifesta et publica instructio morum et fidei, informationi hominum deserviens, ex rationum semita, et auctoritatum fonte proveniens".

12 "Manifesta debet esse praedicatio, quia in manifesto proponenda est (...) Si enim praedicatio occulta esset, suspiciosa esset (...) Publica debet esse, quia non uni, sed pluribus proponenda est. 
Having these characteristics in mind, the historian David d'Avray did not hesitate to characterize the thirteenth-century mendicant friars' preaching as a sort of "mass communication" (D'avray, The Preaching 3-4; Medieval Marriage). In addition to the interior of churches, it often occurred in open spaces suitable for the gathering of a large number of people; in pulpits built outside churches and usually facing a public square; and, in some cases, even on specially built stands (Thompson, Cities 335; Bataillon 24).

Because they were pronouncements aimed at a large audience formed mostly by lay people, this kind of preaching was done in vernacular language. Latin, the idiom in which most sermons were written as model texts, was restricted to learned men and was therefore not used in the oral act aimed at a wide audience. Otherwise, instructing the listeners would not be possible (Kienzle 170; Muessig, Medieval 78-79, 83; C. Delcorno, "Medieval" 450; Constable 132). The exception would be the case of an audience composed of people educated in Latin, such as scholars and religious men.

These features, however, apply to the sermon as a part of preaching, that is, an oral and auricular event. Therefore, it is necessary to ask: how could a sermon, as a written text, carry the characteristic of being public? It is sufficient to point out that in the case of model-sermons the ultimate end of these writings was the preacher's verbal pronouncement -either in its faithful reproduction or merely as the basis and starting point for the elaboration of an original oral exposition. Moreover, it is important to remember that the sermon's text also served to the instruction and edification of the preacher himself or anyone else who read it -a characteristic that led Michel Zink to define this action as "preaching in an armchair"- so that it reached both readers and listeners (Zink 478). Similarly, in the case of reportationes, when produced by lay members of penitent confraternities (as is believed to be the case of Giordano da Pisa's sermons), they are believed to serve as devotional literature material for the use of the confreres themselves, who read them individually or collectively. Reportationes, it is supposed, could also have been used as a basis for lay preaching that, according to the Italian philologist and literary historian Carlo Delcorno, actually took place in the fourteenth-century Florence (C. Delcorno, "Medieval" 461, 483).

Moreover, Alain de Lille himself pointed out that preaching can also take place in writing. The theologian stated: "There are three kinds of preaching. One

Si enim uni tantum proponeretur, non est preadicatio, sed doctrina (...) Praedication enim est illa instructio quae pluribus sit, et in manifesto, et ad morum instructionem”. 
is in the utterance of the word (...) The other is in the writing, for the Apostle said that he preached to the Corinthians because he wrote epistles to them [1 Cor. 5, 9]. The other is in deeds, for it is said: "Every action of Christ is an instruction for us", (Alanus col. 113). ${ }^{13}$ In addition to presenting actions as a form of preaching, Alain also adds Paul's Letters as example of a specific type of preaching. In conjunction with Zink's perspective, it is certainly possible to state that the sermon, as a written text, also turned itself to the instruction on customs and faith. According to Carlo Delcorno, written sermons and letters could be very closely related since epistles were written, like those of the Apostle, for the strict purpose of spiritual direction. This is the case, for example, of Saint Dominic. The founder of the Order of the Friars Preachers wrote several letters to the nuns of the Corpus Christi convent in Venice, epistles in the form of a sermon. Moreover, according to Carlo Delcorno he sent proper sermons along with the letters he dispatched "as texts of edifying literature" (Delcorno, "Medieval" 491). ${ }^{14}$

Still according to the formulation of Alain de Lille, the instruction promoted by preaching would refer to faith and customs. Precisely for this reason, two parts of theology would be implied on it: the rational one, which seeks the divine science; and morality, which offers instruction in customs (Alanus col. 112). As for the aspects of religious beliefs, sermons were used to initiate or develop faith and theological knowledge, to enable catechetical education, and even to oppose movements considered heretical -thus reinforcing dogmatic conceptions within the Church (Muessig, Medieval 4; C. Delcorno, "Medieval" 449, 451, 456-457). Regarding custom, it should inform the public about what is -or should be, in a hypothetical, exemplary and perfect situation- socially accepted and what is not. In this sense, besides reinforcing principles already current in a community, preaching could even be used as what seeks to constitute a style of existence or mode of life (Lefort 2-3). According to the historian Kimberly A. Rivers, dealing with custom issues is a feature of the modern sermon when compared to the old homiletical form. As the author expressed, "in the new sermon style, more emphasis was placed on moral persuasion reinforced by numerous, authoritative quotations than on explanation of the scriptural text". In this sense, Rivers states that Alain de Lille's own definition would be a piece of evidence on this shift (Rivers 151-152). ${ }^{15}$

"Sunt autem tres species praedicationis; una quae est in verbo (...) Alia est in scripto, unde Apostolus dicit se praedicasse Corinthiis, quia eis epistolas scripsit. Alia est in facto, unde dicitur: 'Omnis Christi actio nostra est instruction'”.

14 Other examples and bibliographic references are provided by Kienzle (169, 171).

15 Using an article by Jean Leclerq entitled Le Magistère du prédicateur au XIIIe siècle, the author also quotes, without indicating the preacher, another definition of preaching that reads: "Preaching 
As a source material and/or medium for these two types of instruction, Alain points out that contrary to the preaching conducted in the manner of the Pharisees or heretics, "that propose true things and consequently plant false ones", "preaching must have its true measure in the Sentences"; it must be based on theological authority and mainly on its own foundations, that is, especially in the Gospels, the Psalms, the Pauline Epistles, and Solomon's books of Wisdom, "because the instruction of morality especially stems from them" (Alanus col. 113). ${ }^{16}$ In other words, it is from the scriptural texts that the formation of men and, consequently, of the Christian society with their shared religious beliefs, practices and customs, should occur by means of preaching.

Since this article proposes to establish a synthetic concept of preaching in accordance with the statements and ideas expressed by Friars Preachers in the second half of the thirteenth and early fourteenth century, it is necessary to approach Dominican documentary sources that somehow address sermon and/ or preaching and which have been produced within the time frame established for this research. Thus, according to Siegfried Wenzel's survey Medieval Artes Praedicandi: a Synthesis of Scholastic Sermon Structure, there are only two treatises of Dominican provenance for this period that can be considered as Artes: the Eruditione religiosorum praedicatorum by Humbert of Romans (1190/1200-1277), Master General of the Order of Friars Preachers between 1254 and 1263, written in Lyon after his time as leader of the institution; and the Libellus artis predicatorie by friar Jacobus of Fusignano (? -1333), probably composed in the 1290s (Wenzel, The Art 3; Medieval 12, 17-18). Subsequently, the examination of sermons themselves will be added to the analysis of these two works, taking as source material two reportationes of friar Giordano da Pisa's preaching, active in Florence and in his hometown between 1302 and 1311.

is the true public proclamation of God's word exhorting honest things and forbidding illicit ones" [ "Praedicatio vero est verbi Dei publica annuntiatio jubens honesta, prohibens illicita"] (Rivers 159 , n. 35). Regarding the proper ways of the modern sermon, the definition of preaching by John of Wales, a Franciscan friar who in the thirteenth century wrote an ars praedicandi entitled Ars faciendi sermones, is iconic: "By invoking God's help, preaching is the division and confirmation of the thema proposed by a clear and devout exposition to enlighten the mind about the Catholic faith and charitatively ignite the heart" ["Predicacio est, invocato Dei auxilio, propor[s]iti thematis dividendo et concordando congrue clara et devota exposicio, ad intellectus catholicam illustracionem et affectus caritativam inflammacionem "] (Rivers 152, n. 10).

16 "(...) quia vera proponunt, et consequenter falsa interserunt (...) In sententiis vero debet habere praedicatio pondus (...) Quia in his specialiter resultat moralis instructio”. 


\section{HUMBERT OF ROMANS' DE ERUDITIONE RELIGIOSORUM PRAEDICATORUM}

Although written by an exponent of authority within the Order of Friars Preachers, to the point of being elected as its Fifth Master General, the treatise De eruditione religiosorum praedicatorum does not seem to have been much publicized even in its own time. In the words of Simon Tugwell, scholar of the history of the Order, "it does not seem to have been enormously succesfull in the Middle Ages and it is not very well known in our own time (...)" (Tugwell, Early Dominicas 2); “(...) the order itself preserved almost no memory of it for several centuries and it was rediscovered only at the beginning of the seventeenth century" (Tugwell, Ways 138). Such a judgment, of course, stems from the amount of manuscripts that have been preserved. When the Master General of the Order who held office between 1601 and 1607, Jerome Xavierre (1546-1608), ordered a massive search in all Dominican provinces for documentation produced by the friars at the beginning of the Order (i.e., until the late thirteenth century), only one manuscript containing De Eruditione praedicatorum was found in a Portuguese convent. After the publication of its first part $^{17}$ in 1607 by the provincial prior of Aragon, Simon Bauça (1552-1623) ${ }^{18}$ the manuscript was somehow lost. After this incident, only four other manuscripts were found, three from convents located in Spain and one of French provenance ${ }^{19}$ (Tugwell, Early Dominicans 2-3; Ways 138). ${ }^{20}$

Nevertheless, Tugwell himself argues that despite the probable little dissemination of the text between the thirteenth and seventeenth centuries, it must be regarded with greater esteem by historians and anyone interested in the history of the Order. The reason for this lies in the fact that in the face of the Dominican spirituality problem -that is, a sort of inexistence of thirteenth-century spiritual works produced by the Friars Preachers (Tugwell, Early Dominicans 1-6)- it was perhaps the only copy of this kind of literature produced in the first hundred years of

17 The work consists of two parts: the first is devoted to the qualities of the preaching office, those needed by the preacher, and various other aspects of the preaching office, while the second offers 200 ad status sermons for various occasions (Wenzel, Medieval 12).

18 The edition employed in this article is precisely this one.

19 The four manuscripts that contain the first part of Eruditio praedicatorum are in Avignon, Salamanca, Madrid and Segovia. Except for the second one, dated to the sixteenth century, it seems that all the others were produced in the fifteenth century. There are, however, other manuscripts that contain only the second part of the work (Tugwell, Early Dominicans 2, 477).

By contrast, Mulchahey states that the text was widely popular. According to the historian, one of the reasons for this would be the fact that it presents the model-sermons in its second part (478479). However, these statements lack substance since the author has not provided evidence on this high esteem. As stated, according to Tugwell, the number of manuscripts remaining indicates the opposite of what Mulchahey stated. 
the Order. Moreover, "(...) Humbert's was the only attempt made in the Middle Ages to present preaching like this as a focus for a person's whole life and spirituality (...)". Taking these reasons into account, Tugwell says that De Eruditione was worthy, and still is, of a better fate and "perhaps deserves the title 'Dominican spiritual classic" (Early Dominicans 2). Besides, since it is one of two thirteenth-century Dominican works that specifically address preaching, it cannot be exempt from analysis because of its apparent small popularity at its own time.

In the broad context of Humbert's life within the Order (1224-1277), this feature of the De Eruditione is certainly connected to the oppositions that both Friars Preachers and Minor faced in the kingdom of France with respect to their preaching activity. Humbert was no stranger to the ecclesiastical conflicts of this kind: in 1235 he acted as an intercessor in a dispute between Friars Preachers and Canonists in Bensançon over pastoral responsibility; in the same year that he was elected Master General of the Order (1254), the Parisian traditional clergy unleashed attacks on the mendicant friars, resentful of their massive presence in the university and in preaching activities. In this quarrel, Humbert played an important leadership role in the defence of the mendicant friars and, by the end of the year, they had the full support of Pope Alexander IV -although the conflicts extended at least until 1256 and resurfaced in 1269 (Tugwell Early Dominicans 33). In view of these struggles, his tract on the formation of Preachers can be considered as a powerful apology of the Order itself, declaring preaching as its very foundation.

Beginning with a biblical passage, Humbert used the words of St. Paul's Epistle to Colossians 4,17 as the first in the preface to the book: "Look to the ministry which thou have received in the Lord, that thou fulfil it". By means of these words the friar warned those who are preachers about the necessity to consider their office with the utmost diligence. According to the author,

It is often the case that whoever holds an office and does not know what concerns it by ignorance do it badly (...) because of this, [St.] Paul, wishing that the bishop [Archippus] who held the office of preaching to the Colossians commendably fulfilled it, made him a warning to consider the praiseworthy ministry as contained in the proposed words, to commendably take his consideration to fulfil it well and fully. Thus it is evident that the preacher must diligently study to see precisely what the office of preaching consists of and what is pertinent to that office (Humbert 1-2). ${ }^{21}$ ignorantia peius facere officium illud (...) Propter hoc Paulus desiderans quod Episcopus, qui 
With precisely this warning in mind, Humbert produced his De Eruditione praedicatorum, that is, his instruction of Preachers so that by its reading these men could be informed of all that pertains to their office (Humbert 2).

Taking the title into consideration, it should be noted that the work is not an Ars praedicandi. In other words, it is not a treatise on sermon composition techniques, a work "whose major aim was to instruct beginning preachers in composing their sermons in conformity with the 'modern' usage" (Wenzel, Medieval XV). ${ }^{22}$ In a different way, its author presented everything that he considered to be indispensable in the formation not of a man who among other occupations sometimes preached, but of a man whose very existence should be structured around his vocation to exercise the office of preaching (Tugwell, Early Dominicans 2).

Precisely regarding the characteristics of preaching, the first chapter of De Eruditione deals with "How excellent is this office" (Humbert 2-4). ${ }^{23}$ According to Humbert, its excellence was due to the fact that it is synchronously 1) apostolic, because God chose twelve apostles and sent them to preach;2) angelic, because angels also preach; ${ }^{24}$ and finally, 3) divine, for God became man precisely to preach. Furthermore, in dealing with the motives that make it an

susceperat officium praedicationis super Colossenses, illud laudabiter impleret, fecit eum moneri, ut consideraret ministerium huiusmodi, sicut continetur in verbo proposito, ut huiumodi consideratio ferret eum ad illud bene implendum et plene. Ex quo relinquitur argumentum, quod praedicatori cuilibet est attendum diligenter ut videat diligenter quod sit officium praedicationis et que pertinent ad ipsum officium".

22 Despite listing the work in his Medieval Arts Praedicandi, Siegfried Wenzel draws attention to this fact. According to the author, compared to other works, the De eruditione praedicatorum -as well as the works of Guibert of Nogent (1055-1124) and Gilbert of Tournai (1200-1284), also listed in his survey-is not of the same importance to the goals of his research on the techniques of sermon composition (Medieval 3). Specifically, about this work, Wenzel states that it consists of "a treatise on preaching in general, containing two books (...) and includes scattered remarks about sermon technique (...)" (Medieval 12). Likewise, Mulchahey points out that "the De eruditione is less a handbook of style than it is an essay on the preaching ministry and on the preacher" (476). "Quam excellens sit istud officium".

In one of the sermons preached in Florence on the first chapter of the book of Genesis in 1305, Giordano da Pisa draws a parallel between the angels' hierarchy and that of the Church on Earth; in so doing, he states: "Archangels are said preachers and doctors, for as the archangels reveal and teach about the salvation of the people, so the preachers and the doctors of the Holy Church do so by the teaching of the people and preach for the salvation of all" [ "Arcangiolo sono detti $i$ predicatori e i dottori; chè siccome gli Arcangioli rivelano e ammaestrano della salute del popolo, così i Predicatori e i Dottori della Santa Chiesa sono sopra l'ammaestramento del popolo e predicano la salute di tutti'] (Giordano, Prediche del Beato F. Giordano 195). In this passage, it is already possible to glimpse the purpose of preaching: salvation; the same one that Humbert also identified, as will be seen later on. 
angelic office, the friar eventually revealed its end when he stated that just as the angels "were sent because of those who inherit salvation, so the preachers do for the salvation of man" (Humbert 2-3). ${ }^{25}$ For the first time in the work, Humbert revealed the main purpose of the preaching ministry: salvation. Moreover, from the fact that God became man in the person of the Son precisely to preach, it follows that the proper foundation of the Church -broadly understood as all the faithful, not only the clergy- would have been established by preaching.

After exposing these arguments, the author shifted the focus of his discussion. Without any warning or explanation for this change, the friar went from addressing preaching to discussing Sacred Scripture in a similar way, that is, by exposing the three excellences that it possesses over other sciences. Precisely, these excellences would concern 1) its author, who is God;2) its matter, which would be divine things, such as the holy trinity, divine unity, the incarnation of the Son of God, and other matters to which nothing surpasses; and 3) its end, precisely eternal life (Humbert 3). After explaining these three scriptural excellencies, Humbert clarified the reason for the change of focus on the subject matter by explaining the close relationship that would exist between the sacred text and the preacher's office:

Therefore, because of these [reasons] the Holy Scripture is called theology, because theos means God, and logos means word [sermon], because their words [sermones] come from God, speak of God, and lead to God. Thus from these true words [vero sermonibus] all true preaching must be woven, not from the words [verbis] of other sciences (Humbert 3). ${ }^{26}$

First of all, it should be noted that in this passage there is a wordplay of extreme sophistication that unfortunately is lost in the translation from Latin to English. Humbert enjoyed the fact that the Latin term sermo can mean both word and sermon. Thus, when he spoke of the words of Holy Scriptures -of which, as he said, the weaving of all true preaching must be made- the friar used the term sermo. However, when referring to words of sciences other than theology, he used verbum. Thus, he created a whole chain of meanings related to the office

“(...) cum mittantur propter eos qui haereditatem capiunt salutis: sicut praedicatores propter hominum salutem".

26 "Ex his est quod sacra scriptura dicitur teologia, a theos, quod est Deus, et logos, quod est sermo, quia sermones eius sunt a deo, et de deo, et ad deum. De huiusmodi vero sermonibus texitur omnis vera praedicatio, non de verbis aliarum scientiarum". 
of the preacher: he alluded to the idea of word, but with extraordinary subtlety also to that of sermon. Thus, true preaching would therefore be composed of true sermons, from the words of the Scriptures. It must, therefore, deal with the Holy Scriptures -the true words par excellence- so that by them the souls of men can be saved.

In accordance with these determinations, of all the multiple sciences that a preacher should master, the first would relate to Holy Scriptures, "for all preaching is to be made of scriptural facts, just as read in Psalms [103, 12], 'from the midst of the rocks', that is, from the two Testaments given to you. And this the preachers cannot do without its knowledge" (Humbert 26) ${ }^{27}$ Moreover, it can be concluded that since the end of Holy Scriptures is eternal life, so should also be the aim of preaching, because its discourse must necessarily be made out of them. This, then, was revealed by Humbert in the first chapter:

Preaching then speaks about man, as it was said to the apostles in the last chapter of the Gospel of Matthew: 'Preach the gospel to every creature', ${ }^{28}$ that is, to man. According to Augustine, it is not about the body, but about the soul. So when Peter preached, as clearly is stated in Acts IV, ${ }^{29}$ about three thousand souls were present, for preaching seeks souls: it does not seek things adjacent to them, but only those pertaining to salvation. And it is also said in Luke 1 [, 76-77] of the preacher's [i.e., John the Baptist] excellence: Thou shalt go before the face of the Lord to prepare His ways, to give His people knowledge of salvation (Humbert 3-4). ${ }^{30}$

"Cum enim omnis praedicatio debeat fieri de factis scripturis, iuxta illud Psalmi, de médio petrarum, idest, duorum testamentorum, dabunt voces: et hoc non possint facere praedicatores nisi hebeant eorum scientiam (...)".

28 It is, however, the passage found in Mark 16,15, in which Christ appeared to eleven of the disciples "and he said to them: "Go forth to the whole world and preach the Gospel to every creature". In the last chapter of the Gospel of Matthew there is no reference to preaching. In fact, the correct reference is Acts 2, 14-41. Verses 14-37 reproduce Peter's preaching, while the conversion of the three thousand men is narrated by verses $38-41$.

30 "Praedicatio autem versatur circa hominem: unde Math. ultimo dicitur Apostolis: praedicate evangelium omni creaturae, idest, homini, secundum Aug. Non autem circa corpus, sed circa animam. Unde praedicante Petro signanter dicitur, Actuum.4. quod appositae erant animae circiter tria milla, quia praedicatio quaerit animas: non autem quaerir circa eas, nisi quae pertinente ad salutem. Et ideo dicitur Luc.1. de excellenti praedicatore. 'Praeibis enim ante faciem domini parare vias euis, ad dandam scientiam salutis plebe eius'”." 
Therefore, it would be imperative to hear God's words more than any other, for they would be more useful precisely because those other words concern themselves with earthly things -such as laws, the body's health, and truths concerning other sciences apart from theology- while they deal with the soul and its salvation (Humbert 70).

By a different argument, the repetition of the affirmation of this very end of preaching can also be found in chapter II, which deals with "How Necessary is the Office of Preaching for the Whole World" (Humbert 6-8). ${ }^{31}$ Humbert stated in it: "Nothing so quickly leads to the consummation of joy in heaven as preaching"; "Without preaching the fullness of heavenly glory is not consummated" (Humbert 4-5). ${ }^{32}$ This would be accomplished by this activity precisely because it is a form of instruction, a teaching and learning action by which it is possible to get rid of eternal damnation -for one gets to know himself and his faults (Humbert 61) - and thus realize the glory of Heaven -for one learns what pleases God and those who are together with Him: ${ }^{33}$

31 "Quam necessarium sit officium praedicationis toti mundo".

32 "Nihil autem valet ad huiusmodi consummationis accelerationem, sicut praedicatio (...) sine praedicatione non consumabitur plenitudo gloriae caelestis".

33 In this regard, Chapter III deals exclusively with "How agreeable this office is in the eyes of God" (Quam accpetum sit Deo istud Officum). In it, as conclusion it is said: "From this, one notices how much this office is agreeable in the eyes of God. From what has been said, the holy preaching is received by God as though it were a sweet song (...) Not only by Himself but also by His assistants in His curia, as stated in the last chapter of Song of the Song [8, 13]: 'Thou that dwellest in the gardens, the friends hearken unto thee, make me to hear thy voice'. According to the Gloss, 'friends' means the angels and the righteous spirits, who are one with God" [ "Ex quo apparet quam acceptum sic hoc officium Deo. Colligitur ex iam dictis, quod praedicatio sancta accepta est Deo tanquam cantus dulcissimus (...) non autem solum sibi sed assistentibus sibi in curia sua. Canti. Ultimo. 'Quae habitas in hortis, amici auscultante te, fac me audire vocem tuam': Glosa. Amici, idest, Angeli et spiritus iusto um qui cum Deo sunt"'] (Humbert 8-11, emphasis added). The comparison of preaching with a very sweet song is extremely interesting insofar as the eternal state of glory, just mentioned in the text and in which the angels and the righteous spirits will find themselves after the end of time, consists precisely in the continuous singing in praise to God. As the Italian philosopher Giorgio Agamben sums up after a thorough analysis of the sense of power and glory in Christian theology, "the paradisiacal liturgy ends up in doxology; it knows no mass but only the hymn of praise" (210). Thus, in establishing this comparison, in addition to determining a close relationship between preaching and the liturgy of praise (epaenetic liturgy) (Agamben 172) -insofar as giving a sermon is thus a doxological act- Humbert conceives preaching as a prefiguration of eternal glory. In this sense, as Agamben points out, bishop William of Auvergne (ca. 1180/90-1249) provided in the thirteenth century a definition of glory that establishes this identity with preaching. In his work De retributionibus sanctorum, he stated: "another meaning of what is named the glory of God is that through which he is glorified, that is, honored, preached about, praised, and adored by the elect and by all men" (Agamben 214, emphasis added). 
The defect of knowledge, therefore, fills up hell. Preachers, however, fill up the Earth with knowledge as it is said in Proverbs 15 [, 7]: 'The lips of the wise pour out knowledge'; and also in the Gloss is said about preaching: From this, then, it is evident that preaching reverses the fullness of hell (Humbert 5). ${ }^{34}$

Regarding this pedagogical feature of preaching, in chapter $\mathrm{V}$, which clarifies "How useful it is, especially for men" (Humbert 17-19), ${ }^{35}$ Humbert stated that " $(. .$.$) there are many who, because of simplicity, err in many things.$ But preaching, by the exposition of the word of God, instructs them, as it is said in Psalms [118, 130]: 'The declaration of Thy words giveth light, and giveth wisdom to little ones" (17). ${ }^{36}$

The possibility of attaining salvation brought about by preaching, however, would not concern only those Christians who commit sins. According to Humbert, faith in Christ is also of great necessity for the "barbarian nations". There would be no other way for them to obtain it but through this office. Using the words of St. Paul in the Epistle to Romans 10, 14, the friar rhetorically asked: "How shall they believe in Him, of whom they have not heard? And how shall they hear if no one preaches?". And he himself added: "Therefore, the Lord gave to the preachers of Christ all kinds of tongues, so that what they preached might be intelligible and that they might bring all to faith. Thus, it is manifest that all nations cannot be converted without preaching" (Humbert 5) ${ }^{37}$ In other words, if the preachers failed to exercise their office, infidelity would persist in the world (Humbert 61). According to this understanding, in its very beginning the Church itself, as an institution and mystical body of Christ, could only have been established by preaching: "Likewise, without preaching the Church would not have been founded" (Humbert 5). ${ }^{38}$ In chapter XXVII, which speaks of the great fruits of preaching (De fructibus optimus praedicationis), ten of its best results

"Defectus ergo scientiae facit ad repletionem inferni: praedicatores vero replent terra scientia: Proveb.15. Labia sapientum disseminabunt scientiam: Glosa, praedicando. Ex hoc ergo patet quod praedicatio retrahit repletionem inferni".

35 "Quantum sit utile specilaliter hominibus".

36 “(...) sunt multi qui propter simplicitatem errant in multi: sed praedicatio per expositionem verbi Dei instruit eos: Psal. Declaratio sermonum tuorum illuminat et intellectum dat parvulis".

37 “(...) barbari nationibus (...) 'Quomodo credent ei, quem non audierunt? Quomodo autem audient sine praedicante?'. Et ideo Dominus dedit praedicatoribus Christi genera linguarum omnium, ut praedicantes omnibus inteligiliter, omnes ad fidem istum possent pertrahere. Et sic manifestum est quod tot nationes sine praedicatione non esst ad Christum conversae". "Item sine praedicatione non esset Ecclesia fundata". 
were listed. Among them, the seventh would be the "increase of the mystical body of Christ. For by preaching many are added to him. According to Acts II [, 41] 'and on that day nearly three thousand souls were added', that is, by the preaching of Peter" (Humbert 69). ${ }^{39}$

In addition to all these features, according to the precepts of the Eruditione, preaching would not only be important in matters concerning faith, divine things (Humbert 3). Since preachers are said to be soldiers of Christ, this office, besides being a struggle against the errors of infidelity, would also be a battle against the errors of custom (Humbert 8). This means that the preacher must be an active agent in shaping a shared way of life by a society, an authority that presents to those who hear him the norms that establish what is right and wrong, just and unjust, and what should be desired and what should be rejected. Thus, one of the harms of not preaching would be "the error of customs":

(...) as a result, many err on how to act, ignorant of what is lawful and what is not. Thus they advance in the ways of evil, for they are not enlightened by preaching about these things. In Wisdom 5 [, 6] it is said of the damned: 'We have erred far from the way of truth: and the light of justice hath not shined unto us'. That is, because the light of justice did not illuminate us. And what then is the light of justice if not preaching, which boasts that which is righteous and that which is unrighteous? (Humbert 61). ${ }^{40}$

Considering all that has been exposed and explained so far about the Eruditione, it is possible to elaborate an Humbertian concept of preaching that can be expressed as follows: Preaching is an instruction concerning divine things and customs, carried out from the words of the Holy Scriptures and whose goal is salvation. Despite placing greater emphasis on salvation, instruction on faith, and divine things regarding the standardization of customs, it can be noted that Humbert of Romans' idea of preaching was very close to that presented by Alain de Lille in his Summa de arte praedicatoria (Alanus col. 111, 112). Actuum.2. 'et appositae sunt in die illa anime circiter tria milla', scilicet, ad praedicationem Petri". "Item error in viam morum, propter hoc enim multi errant circa agenda: nescientes quid liceat et quid non. Ei ideo per vias malorum operum incedunt: quia non sunt illuminati per praedicationem circa ista. Sap.5. dicunt damnati. 'Erravimus a via veritatis: et iustitiae lumen non luxit nobis', idest, quia lumem iustitiae non illuxit nobis. Quid autem est lumen iustitiae nisi praedicatio, quae ostendit quid sit iustum, et quid sit iniustum?". 
While on the one hand this does not necessarily means that the Friar Preacher actually employed the work of the theologian, on the other hand it is certainly an indication that there was, at least from the late twelfth century until the midthirteenth century, a conception of preaching widely spread among learned men that dealt and reflected on this office: according to the works examined so far, it was considered, above all, as a normative action of the social life, both in relation to their religious beliefs and to their shared customs and practices.

\section{JACOBUS OF FUSIGNANO'S LIBELLUS ARTIS PREDICATORIE}

Noticeably different from his confrere's work -both in popularity (Wenzel, The Art 3$)^{41}$ and in its content and format- the Libellus artis predicatorie by Jacobus of Fusignano, ${ }^{42}$ probably written around 1300 in Italy, is in fact a complete Ars praedicandi: it addresses all aspects concerning the production of a sermon according to the modern style, as it was called at the time (Wenzel, The Art 4). As for its influence, and specifically regarding the preaching of Giordano da Pisa (c. 1260-1311), Carlo Delcorno believes it is likely that the friar from Pisa read Jacobus's treatise since the book pays attention to the problem of preaching for lay people. He also points out that the schemes presented by Jacobus serve very well to explain the structures of his sermons (C. Delcorno, Giordano 88). From this affirmation and in the same sense, historian Marian Michèle Mulchahey stated -certainly with more emphasis on the undoubtedness of this influence than Carlo Delcorno himself- that

41 According to Wenzel, the "Libellus artis predicatorie (...) enjoyed much popularity: it survives in more than twenty manuscripts, including one of English provenance (...), and was included in several incunable editions of the equally very popular Manipulus curatorum, a pastoral manual written in 1333 by Guido de Monte Rocherii (or Rochen)". For his editing and translation of the work, Wenzel employed three manuscripts produced in the fourteenth century, one of which is of Italian origin (Wenzel, The Art 4-6).

42 Jacobus of Fusignano was a friar Preacher of the Roman province which held various offices within the Order at the turn of the thirteenth century to the fourteenth. He was first appointed minister general of his province (1288); then prior of the convent of Santa Maria sopra Minerva in Rome (1289-1290); and, finally, second provincial prior of the newly founded Province of the Kingdom of Sicily (1298-1301). He was also the executor of the will of cardinal Latino Malabranca Orsini (?-1294) and chaplain of Charles II of Anjou (1299) - who, in 1299 and again in 1308, appointed him as legate to Genoa, Italy. Also, in 1308 he was made bishop of Lucerra by pope Clement V (1305-1314), a position which he held until 1322 when he was made bishop of Methoni, Greece, an office that he occupied until his death in 1333 (Wenzel, The Art 3; Charland 50; Mulchahey 403; Harper 189-191). 
Fra Giacomo's work seems to have exerted a certain influence upon Dominican preachers in Tuscany, including Giordano da Pisa, who evidently studied the tract quite closely. The Libellus may have interested fra Giordano because it devotes so much space to a consideration of the problem of popular preaching, which was, after all, Giordano's strong suit. Whatever his reason, Giordano da Pisa exhibited a great fidelity to the sermon schemes described by Giacomo da Fusignano when developing the structure of his own sermons (Mulchahey 475-476).

Despite the categorical assertion, the author herself recognizes the circularity of the argument, that is, the possibility that the work of Jacobus may have been the result of the observation of the practice of other friars in popular preaching. Thus -in a consideration that seems to better represent and/or explain the case- "(...) the similarities between the tract of the one and the sermons of the other may, in fact, be the result of both men expressing a common tradition, one as codifier, one as practitioner" (Mulchahey 476, n. 226).

Divided into nineteen chapters, the Libellus establishes in a very enlightening way the four (Aristotelian) causes of preaching (chapter I), the guidelines for choosing a thema (II and III) and prothema (IV), and the several possible division modes that can be applied in a sermon construction (V-XIX) (Wenzel, The Art 4; Medieval 18). Due its contents concerning the techniques of the art of sermon production, out of all nineteen chapters, the first one together with some passages from chapters II, XI and XVIII- is of the utmost interest to the objectives of this research. Since the purpose of this article is to understand what a sermon is in terms of its goal and provide a synthetic concept regarding preaching - and not to examine its writing procedures- the first chapter is important as it sets out the causes of this activity. In turn, the second, more than stablishing that the sermon must absolutely be a discourse/text that originates from a biblical passage, explains the reasons for this determination and, therefore, makes some considerations about the preachers' tasks. Finally, chapters XI and XVIII present some enlightening reflections on the purpose of preaching, and it is, therefore, imperative to analyze them.

The Libellus does not have a proper prologue. The first words found in the manuscripts form an inscription that reads only: "Here begins the booklet on the Art of Preaching, composed by Friar Jacobus of Fusignano of the Order of Friars Preachers". This sentence is followed by the first chapter, entitled "On the four causes of divine exhortation". It is opened by the passage from St. Paul's Epistle to Philippians 1, 9-10 which states: "I pray that your charity may more 
and more abound in knowledge and in every sense, that you may test the better things and be sincere and without reproach unto the day of Christ" (Jacobus $10,11) .^{43}$ Jacobus applied to these words the procedure of inquiry into the four causes as set forth by Aristotle (384-322 BC) and, in so doing, revealed some of the characteristics of preaching as he understood them.

As stated by the Philosopher in his works Physics and Metaphysics, it is only possible to understand something from the moment one knows their reasons, that is, its cause. However, this cause can be identified in four senses: 1) cause means that from which something is created, its matter, like the bronze used in a statue and the silver used in the manufacture of a vessel; 2) it is also the shape or pattern, as with a sequence of words in a sentence or with numbers in a fraction; 3 ) it also means that which initiates a change or establishes rest, as the person who deliberates is the cause of what is done later, the father the cause of the child, and the one who does what is done or whatever change something that changes; 4) and finally, cause is also the end, that is, the final cause of something, as health is for walking -for why does man walk? "To be healthy," one answers (Physics, II, 194b; Metaphysics, V, 1013a).

Having explained these four causes, Jacobus stated:

These four things also apply to the teaching of holy knowledge, and they can be conveniently found in the [biblical] words that have been quoted. The efficient cause in divine exhortation is twofold, one principal, the other instrumental. The principal cause is God (...) Here the principal efficient cause is expressed in the words 'I pray', namely to God, the principal agent of preaching. But the instrumental cause is the preacher, whose tongue must be moved by God to preach, after the words of the Psalm 'My tongue is the pen of a scribe'. For it is Christ who speaks of the truth through the preacher (...) Hence the instrumental efficient cause is indicated [in the initial quotation] by the words 'your charity'. But the formal cause appears in the words 'that it may more and more abound'. For the preacher must abound variously in authorities, reasons, similitudes, and examples (...) And the material cause is indicated when our [initial] authority concludes with 'in knowledge and all understanding'. By saying 'in knowledge' it fratrum predicatorum. Primum capitulum: De quatuor causis divine exhorattionis. 'Oro ut caritas uestra magis ac magis habundet in scientia et in omni sensu, ut probetis pociora et sitis sinceres et sine offensa in diem Christi". 
indicates the cognizance of divine truth, which alone can be said to be truly knowledge and wisdom (...) Thus the material cause, namely Holy Scripture, is indicated in the noun 'knowledge'. But the authority then adds 'in every sense', for Holy Scripture is full of multiple senses, each of which can be useful to the preacher, as will be shown below. And lastly, the end of preaching is to lead to virtues and to call back from vices and sins. Thus its final cause is indicated [in our authority] when it says 'that you may test the better things', with respect to practicing virtues, and 'be sincere', that is, without the corruption of the flesh, with respect to detesting vices (Jacobus 10-13, emphasis added). ${ }^{44}$

Despite this detailed explanation of the preaching's author, its instrument, its subject, and of its end, its definition would still have some other important features, pointed out and discussed by Jacobus in the second chapter -"The preacher must choose a thema and begin with a prayer". The author began it with a supplementary reflection on some attributes of an instrumental efficient cause -which, as have been seen, would be the preacher. According to Jacobus, three things could be discerned about him: 1) he has an action derived of its own nature -that is, he is an agent- despite the fact that he acts according to the manner in which he is moved by the principal efficient cause; 2) since the first agent - i.e., the principal efficient cause- is said to be the first mover, the instrumental agent, even as an agent, is also itself moved; and 3) the instrumental agent sometimes achieves the ultimate effect (i.e., the end) of the principal agent, sometimes it does not (Jacobus 14). ${ }^{45}$

$44 \quad$ "Unde et ad doctrinam sancte eruditionis quatuor ista concurrunt, que in assumptis uerbis conuenienter possunt notari. Causa namque efficiens diuine exhortationis duplex est, scilicet principalis et instrumentalis. Principalis causa Deus est (...) Vnde causa agens principalis insinuatur cum dicitur oro, scilicet Deum, principalem actorem predicationis. Causa uero instrumentalis predicator est, cuius lingua debet a Deo moueri ad predicandum. Christus enim loquitur per predicatorem ueritatis (...) Causa igitur agens instrumentalis datur intelligi per hoc quod dicitur caritas uestra. Causa uero formalis insinuatur cum dicitur magis ac magis habundet. Debet enim predicator habundare auctoritatibus, rationibus, similitudinibus, et exemplis uariis modis (...) Causa quoque materialis insinuatur per hoc quod in auctoritate concluditur in scientia et in omni sensu. Dicit autem in scientia ad insinuandum diuine ueritatis notitiam, que sola ueraciter scientia et sapientia dici debet (...) Causa igitur materialis, que est sacra scriptura, insinuatur in nomine scientie. Sed addit in omni sensu, quia scriptura sacra habundat multiplici sensu, quorum quilibet potest esse utilis predicatori, ut infra patebit. Finis autem predicationis est inducere ad uirtutes et reuocari a uitiis et peccatis. Unde causa finalis insinuatur cum dicitur ut probetis potiora, quantum ad uirtutum exercicium, et sitis sinceres, idest sine carne corruptionis, quantum ad detestationem uitiorum".

"Quod predicator debet thema assumere et orationem premittere". 
Because of these aspects of the instrumental agent-cause, the author explained that there would be some consequences for preaching. First, by having some action of his own nature when speaking, in addition to acting through God the preacher would also act on his own - precisely when choosing a thema, Jacobus said. Second, because he can be moved despite the fact that he himself is an agent, God would move the preacher's tongue as the principal agent. This, then, would imply that if God does not do so, preaching would not reach its goal -which is to induce men to virtue and to turn them away from vices and sins. Therefore, as stated in the title of the chapter, it would be extremely important for the preacher to say a prayer before beginning a sermon, so that God would bestow His grace and glory. This determination, therefore, was not a simple article of faith, but stemmed precisely from the way preaching worked according to the four Aristotelian causes. As a consequence of the third aspect concerning the instrumental agent-cause, as well as the second, as an instrumental agent the preacher alone cannot achieve divine grace, "for He alone [i.e., God] bestows grace and glory". Again, it would be precisely because of this, and not out of a faith disposition, that the preacher should finish his sermon with a prayer that asks these things to God (Jacobus 16). ${ }^{46}$

Having clarified these particularities of the preaching operation, as well as establishing another end pertinent to it -that is, salvation- it must also be noted that its end, according to the first chapter, also includes inducing men to the virtues and keeping them from vices and sins. Regarding its ends, Chapter XI, "On the development of the sermon by the multiplication of expositions and meanings", is enlightening. Jacobus started it by explaining that the Holy Scriptures have multiple senses, of which the preacher must be aware of three things. Among them, the first is enlightening as to the goal of preaching. The author stated that the preacher must know "in how many and in which senses the Holy Scripture can be explained" (Jacobus 58-59). ${ }^{47}$ As Jacobus explained,

(...) we must know that Holy Scripture contains in one and the same word a multiple sense, namely the literal, moral, allegorical, and anagogical. Their difference can be understood as follows. Since the author of Holy Scripture is God, who has the power to assign meaning not only to words but also to things themselves, some truth can be manifested in Holy Scripture in two ways, literally by words

“(...) cuius solius est gratiam et gloriam conferre (...)”.

"De dilatatione sermonis per multiplicationem expositionum et sensuum (...) est quot et quibus sensibus sacra scriptura possit exponi (...)”. 
and figuratively by things. Manifestation through words establishes the historical or literal sense. Thus it is clear that to the literal sense belongs everything that one understands directly by the meaning of words. But the manifestation of truth which Holy Scripture furnishes figuratively through things has two aims, namely, right belief and right action. If it aims at right action, it is the moral sense, otherwise called tropological. If it aims at right belief, we need to distinguish between different senses according to the order of things that can be believed. The state of the present Church is intermediate between that of the synagogue and that of the Church Triumphant, just as the Old Testament was a figure of the New, as the Apostle teaches in I Corinthians 10. Thus, both the Old and the New Testament are figures of heavenly things. Therefore, the sense furnished figuratively by things that rests on that mode of figuration by which the Old Testament prefigures the New is called allegorical or typical (...) And in general, whenever things that happened in the Old Testament are applied to Christ or the Church Militant, we speak of the allegorical or typical sense. But if the sense furnished figuratively rests on that mode of figuration by which the Old and the New Testament together prefigure the Church Triumphant, then it is the anagogical sense. From what has been said, therefore, it is clear that the literal sense reports what happened, while the allegorical sense indicates what is to be believed about Christ and the Church; the moral sense teaches what we must do; and the anagogical sense, what we must believe about the Church Triumphant, which we should strive to reach (Jacobus 59-61, emphasis added). ${ }^{48}$

"Circa primum autem sciendum est quod scriptura sacra sub una littera habet multiplicem sensum, scilicet litteralem, moralem, allegoricum, et anagogycum. Quorum distinctio sic potest accipi. Cum enim actor sacre scripture sit Deus, in cuius potestate est non solum uoces accommodare ad significandum sed etiam res ipsas, potest in sacra scriptura ueritas aliqua duppliciter manifestari, scilicet per uerba et per rerum figuras. Manifestatio autem que est per uerba facit sensum ystoricum seu litteralem. Vnde patet quod ad sensum litteralem pertinet totum illud quod ex ipsa significatione uerborum directe accipitur. Manifestatio autem ueritatis quam sacra scriptura tradit per figuras rerum ordinatur ad duo, scilicet ad recte credendum et ad recte operandum. Si ad recte operandum, sic est sensus moralis, qui alio dicitur nomine tropologicus. Si autem ad recte credendum, sic secundum ordinem credibilium oportet distingui diuersos sensus. Cum enim status presentis Ecclesie sit medius inter statum synagoge et statum triumphantis, sicut uetus testamentum fuit figura noui, ut docet Apostolus primo Corinthiorum x, ita uetus simul et nouum sunt figura celestium. Sensus ergo traditus per figuras rerum qui fundatur in illo modo figurandi quo uetus testamentum figurat noum vocatur sensus allegoricus seu tipicus (...) Et 
From this passage it is clear that the goal of preaching, as stablished by the friar in the first chapter -that is, to induce men to virtue and to draw them away from vices and sins- would be reached by the exposition of Holy Scriptures in a moral sense. In regards to this, it is important to remember that the Roman philosopher Marcus Tullius Cicero (106-43 BC) named the part of philosophy that deals with customs as moral, inventing the Latin word moralis (from mos, that is, customs, uses) to translate the Greek term $\tilde{\eta} \theta$ os (éthos) (Cicero, I). Therefore, it deals with the manners, the ways of acting, both those that are regarded as right and those considered as execrable -and does so by classifying them as virtuous or fruits of one or more vices. In other words, it is possible to see that, for Jacobus of Fusignano, preaching would be fundamentally a moralizing activity, which defines a set of assumptions about what must be shared by the Christian society as being right and wrong, desirable and abominable, just and unjust, and that should guide the actions of all. An example of this was given when Jacobus explained the third point that the preacher must keep in mind when developing the sermon by multiplying the explanations and meanings. According to the author, one should know that it is possible to expand a sermon by exposing the thema in two different ways. To illustrate this, he took the moral statement from Luke 8, 5: "The sower went out to sow his seed". The sower, in this case, can take on both the penitent and the sinner's meaning. In the case of demonstrating a morally correct conduct -that is, according to the customs and manners of the Christian society- the penitent departs from his sins and reaches glory, and this would be understood by the words went out. Moreover, by seed would be understood his good deeds, which guarantee him the fruit of eternal life. In the second case, in which the sower represents the sinner, he practically goes out of himself by surrendering himself to his sins and denying the judgments of his reason; obviously, in this case his seed would be all the sins that he commits and that bear bad fruits in the future (Jacobus 67-70).

Precisely for these features, preaching can be understood above all as a political action, because by informing about ideal and desired social-political functioning, one seeks to give a configuration and a meaning to an entire society.

generaliter, quando ea que in ueteri testamento contigerunt exponuntur de Christo uel Ecclesia militante, sensus allegoricus uel typicus dicitur. Si uero sensus traditus per figuras fundatur in illo modo figurationis quo nouum simul et uetus testamentum figurant Ecclesiam triumphantem, sic est sensus anagogicus. Ex dictis itaque patet quod sensus litteralis narrat id quod est gestum; sensus uero allegoricus signat quod est credendum de Christo et Ecclesia; sensus moralis docet quod est nobis agendum; sed sensus anagogicus docet quid nobis credendum sit de Ecclesia triumphante ad quam debemus tendere. Vnde facti sunt de hoc uersus: 'Littera gesta docet, quid credas allegoria, Moralis quid agas, quo tendas anagogia",". 
This is made clear in chapter XVIII, "On sermon development by designating or considering causes and effects". According to the author, "if we speak of the goodness of a virtue or the evil of a vice, our sermon can be fittingly expanded by their causes and effects" (Jacobus 90,91$){ }^{49}$ In this regard, two things should be noted by the preacher:

One is that the preacher must not try to specify the causes and effects of just everything at random, but only of those things whose knowledge is helpful in one's moral formation or in praise of the saint whom he is preaching about. Such are the virtues, vices, and their acts, such as prayer, almsgiving, fasting, and the like. Second, such causes and effects should not be specified in order to indicate how many virtues and vices there are but rather to persuade the audience to engage in virtuous deeds and to withdraw them from sins and vices. For the end of moral knowledge is virtuous action and not just getting to know what virtues and vices there are (Jacobus 92, 93, emphasis added). ${ }^{50}$

In conjunction with the previous passage, it is very clear that the exposition of the contents of Sacred Scripture, according to the moral sense, specifically aims at the action, transformation and regulation of relations in a society -and not just mere information.

Having explained this moral purpose of preaching, if the extract quoted from chapter XI is considered, it can be seen that this passage added one more end to the preacher's activity: beyond the goal of virtue and vice, and that of grace and glory, it also serves as an instruction on the right way of believing, both with regard to the Church Militant (in immanence) and the Church Triumphant (in transcendence). In this sense, as already established by Alain de Lille, Jacobus also believed that preaching served to the instruction on faith.

"De dilatatione sermonis per assignationem seu considerationem causarum et e effectuum (...) cum de bonitate alicuius uirtutis uel de malicia alicuius uicii loquimur, potest sermo per causas et effectus eorum conuenienter dilatari".

$50 \quad$ "(...) primum est quod predicator non conetur assignare causas et effectus omnium rerum indifferenter, sed tantum illarum quarum noticia est utilis ad informandum mores uel ad laudem sancti de quo predicatur. Huiusmodi autem sunt uirtutes, uicia, et actus ipsorum, ut oratio, elemosina, ieiunium, et hiis similia. Secundum est quod huiusmodi cause et effectus non tam assignari debent ad ostendendum quot sint uirtutes et uicia quam ad persuadendum actus uirtutum, et ad retrahendum a peccatis et uiciis. Finis enim moralis sciencie est opus et non sola noticia uirtutum et viciorum". 
By assembling all these characteristics presented by the friar, it is possible to establish a sermon/preaching concept that can be announced as follows: preaching is an exposition of the truth found in the Holy Scriptures, made by God through the preacher's speech (who employs authorities, reasons, similitudes, and examples), whose purpose is to induce men to virtue and to remove them from vices and sins; to inform them in matters concerning faith with regard to the Militant and Triumphant Church; and to give them grace and glory, that is, salvation.

\section{PREACHING ACCORDING TO TWO SERMONS OF GIORDANO DA PISA}

Unlike the cases of his two confreres, the Giordanian documental corpus consists exclusively of sermons preserved in the form of reportationes, that is, notes made by another person of the speeches given by the friar in vernacular language. ${ }^{51}$ In total there are 731 texts preserved in 40 manuscripts from the fourteenth and fifteenth centuries, most of which are now found in Italy, but also in France and England. This information is important because in general -that is, compared to the number of existing model-sermons- there are few reportationes of the thirteenth and fourteenth-century preaching. Moreover, the fact that there are systematic records of Giordano's speeches shows, besides his constant work, the great interest that the public had for his sermons.

Having joined the Order of Friars Preachers in 1280 at the Santa Catarina convent in Pisa, Italy, Giordano probably studied in Bologna and Paris (12841286) and later served as lector sententiarum in the convents of Siena (1287) and Perugia (1288), and as lector principais in Viterbo (1295). In Florence, where he remained constantly between 1302 and 1307, he was a professor (lector sententiarum from 1302 to 1304, and lector principales between 1304 and 1307) and a preacher (his appointment to the highest office of preacher, praedicator generalis, happened twice, a year after his arrival and in 1305). After this he returned to Pisa, where he officially resided until the year of his death in 1311. At the occasion, it appears that the friar was heading to Paris to join the University of the city at the invitation of the Master General of the Order, succumbing to some disease while passing through Piacenza, northern Italy (Corbari 55, 57-58; C. Delcorno, Giordano; Iannella, Giordano 26; Bonaini 451; Affò XVII-XVIII, XXII-XXV; Galletti 29-30).

51 About this type of documentation, see Bataillon; C. Delcorno, "Medieval"; Hanska. 
Regarding the preaching activity, the reportationes of Giordano's sermons present passages in which the preacher, in arguing on the subject that was being dealt with, informed his audience of some of the characteristics and purposes of his office. One of these occasions occurred on a Sunday morning, 19 July 1304, while preaching in the church of the Friars Preachers convent in Florence, Santa Maria Novella (Giordano, Prediche del beato fra I 170). In accordance with the Gospel reading ascribed for the Eighth Sunday after Trinity Sunday, Matthew 7, 15-21 (Ordo, Missale 110v.-111; Ordinarium 186), the friar adopted the first verse and part of the second (the first sentence) as thema: "Beware of false prophets who come to you in sheep's clothing, but inwardly they are ravenous wolves. By their fruits you shall know them" (Giordano, Prediche del beato fra I 170) ${ }^{52}$ Giordano then began his speech with a praise of the one who teaches (professor or teacher), highlighting his role as regards salvation, and soon after he established the identification between this person and that of the prophet of the biblical passage:

Among all the things that are necessary for our salvation is the teacher. For without him we cannot prepare for ourselves; for we are born into this world without sense and without knowledge of any creature; aside from speaking, which seems to develop rapidly, man alone would not know if he had not been taught before by the one who knows. Mostly we would be ignorant of all other things that are needed. And the teacher is so helpful that Christ confirmed it when he said: atendite a falsis prophetis. Christ calls them prophets. A prophet is called he who reveals things to come, things that men do not know, such as Isaiah, Jeremiah, and other holy prophets. Prophet is said of one who also says of the present things which are not known to others, such as Saint Elizabeth, to whom the Mother of God came and she knew she was pregnant with the Son of God. Thus she said, 'From where did the Mother of God come to me?' [Luke $1,43]$. And by those words she was called a prophetess. Therefore, by teacher is meant prophet, and by prophet, teacher. And St. Paul in his epistles makes no difference between them, and, therefore, the teachers, who are to teach the people, are often called prophets (Giordano, Prediche del beato fra Giordano I 170-171). ${ }^{53}$

52 "Attendite a falsis prophetis, qui veniunt ad vos in vestimentis ovium, intrinsecus autem sunt lupi rapaces: a fructibus eorum cognoscetis eos".

53 "Infra tutte le cose, che ne fanno mistieri a nostra salut, si è il maestro; perocchè sanza maestro, per noi non potremmo apparare; chè noi nasciamo in questo mondo sanza senno, e sanza 
Having explained this assimilation, the friar soon warned his listeners about the fact that just as "the good teachers are necessary and useful, bad teachers, on the contrary, are dangerous and harmful; the evil that comes out of them has no end". These bad teachers, of course, were to be associated with the false prophets to which the preaching thema referred: "And therefore Christ said: beware of false prophets, that is, of bad teachers" (Giordano, Prediche del beato fra I 171) ${ }^{54}$ Furthermore, it was precisely regarding their action that the friar would highlight the role of preaching.

As the preacher stated, still in the introduction of his pronouncement on the first part of thema concerning the commandment of false prophets, soon after the Ascension of Christ they would be identified as those considered heretics. However, as Giordano explained, in his day they would no longer exist in numbers that offered real danger, and thus the false prophets/teachers could be associated with another category of person, such as those who are guilty in pride (Giordano, Prediche del beato fra I 171-172). In any case, whether heretics or sinners of some kind, by explaining the meaning of the thema's last sentence the preacher stated that since it is impossible to recognize man's heart for its mutability, one could know it by the evaluation of its fruits (Giordano, Prediche del beato fra I 173). Supported by this assertion, Giordano developed his preaching from verse 16 ("a fructibus eorum cognoscetis eos") and compared man with a fruit-bearing tree and God with a gardener.

It is important to bear in mind, therefore, that on the basis of the thema the preacher structured his sermon as follows: in the introduction he dealt with the first sentence of verse 15, the commandment "Attendite a falsis prophetis"; and in the rest of the sermon he addressed the statement of verse 16, its first sentence. By noticing this, it is possible to say that the preaching itself, in fact, dealt more with the ways of recognizing sinners and how to protect oneself from them:

conoscimento d'alcuna creatura; ch 'eziandio il parlare, che pare coì leggieri, l'uomo per se solo non lo saprebbe, se prima non ne fosse ammaestrato da quelli, che'l sa. Maggiormente saremmo ignoranti di tutte l'altre cose, che mistieri ne sono. E perocchè'l maestro è di contanta utilitade, ci ne conforta Cristo quando dice: atendite a falsis prophetis. Chiama Cristo questi, profeti. Profeta è detto quelli, che revela le cose, che deon venire dalla lunga, che gli uomini non le sanno, come fu Isaia, e Geremia, e gli altri profetti santi. Profeta è detto colui, che dice le coze eziandio presenti, le quali non si sanno per gli altri, come di Santa Lisabetta, che venne a lei la Madre diDio, ed ella conobbe ch'ell'era gravida del Figliuolo di Dio: sì disse: come è a me venuta la madre di Dio? E per questa parola fu chiamata profetissa; sicchè per maestro s'intende profeta, e per profeta maestro. E Santo Paulo nelle pistole sue non ci fa di ciò differenza; e però i maestri, c'hanno ad ammaestrare le genti, spesse volte li chiama profeti".

54 "E secondamente ch'e'buoni maestri ne sono così mistieri, ed utili, così per contrario i mali maestri sono pericolosi, e dannosi; el male che dimloro esce, è sanza fine. E però disse Cristo: guardatevi da'falsi profeti, cioè, da'mali maestri'". 
(...) with great care and diligence Christ here teaches you to protect yourself from evil teachers and doctors. Having Christ done this commandment [i.e., Attendite a falsis prophetis], he teaches which are good teachers and which are bad and how we can know them. And so he said: a fructibus eorum cognoscetis eos. You will recognize them by their fruits. The evil tree bears bad fruit; the good tree bears good fruit. The good tree cannot produce bad fruit, nor can the bad tree produce good fruit (Giordano, Prediche del beato fra I 174). ${ }^{55}$

The sermon's thema, therefore, more than "Attendite a falsis prophetis" was "a fructibus eorum cognoscetis eos".

Giordano divided this preaching into four parts: in the first he explained that the fruit of a tree has a certain characteristic that allows for its identification: even if a bad man has certain good attitudes, there will always be one that will definitely contradict the others and denounce his true disposition. Next, he then addressed the softness of the fruit and the thorniness of the tree that enables one to know the quality of the plant, that is, whether a man has a pacified heart or not. Thirdly, he spoke of the root, namely, the will of man; and finally, how God, like a gardener who transposes, prunes, grafts, and plucks certain plants for the good of the garden, does the same for men (Giordano, Prediche del beato fra I 175, 176, 177, 178).

In addition to the introduction already analysed, the most relevant part of the reportatio for the purpose of this article is the first. In explaining that the fruits of evil teachers have features that allow men to distinguish between those who are indeed good and those who are evil, Giordano stated that it would be necessary, first, for men to instruct themselves in the doctrine of Christ. The reason for this is that it is the good fruit itself: by knowing it, one would recognize, by antinomy, the bad fruit, and its producer, that is, sin and the sinner. This learning, in turn, would be offered no less than by preaching:

The good and the bad together agree on many things, for which you would not recognize one from another (...) But for certain things they differ themselves in certain characteristics (...) First, I say that there is a feature in the fruit; and what is this? When you see a man who guards Fatto Cristo questo comandamento, sì ne ammaestra quali sono $i$ buoni, e quali sono i rei, e come noi li potemo conoscere. E però disse: a fructibus eorum cognoscetis eos. Voi gli cogscerete a'frutti loto; la mala arbore fa malo frutto, la buona arbore fa buono frutto. Non può la buena arbore fare mal frutto, nè la mala arbore fare buon fruto". 
himself from mortal sins, see that he is in prayer, he is in the fruit of penance, that is, that he confesses, gives away to others, and produces other good fruits. These things the bad ones do not do. But the wicked, though you see that some give alms or fast, yet if you see that they are fleshly, lustful or stupid, murderers, deceivers or detractors, and are in mortal sin, you will see them as evil verminous trees. Similarly, if you see them with a bad teaching of sin or heresy, which do not agree with the teachings of Christ, you will see them as bad trees, although this heresy they do not say it openly, but they say it quietly, in secret. Therefore, one must be industrious in coming to preaching, where the doctrine of Christ is taught. It should not be done for any other reason than that whoever uses preaching know very well the words that contain heresy and know them thoroughly; know how to guard and defend himself when necessary. But others, who do not come to preaching, how will they know them, how will they defend themselves when necessary? And that is why preaching is very useful. There is no one who, coming to preaching, does not hear a useful word that does much for him. Thus, by the characteristic of these fruits, the good and the bad are well known as well as who is wise (Giordano, Prediche del beato fra I 174-175). ${ }^{56}$

From this passage it is possible to see that one of the functions of preaching highlighted by Giordano would be to inform men in a moral sense, that is, to clarify which actions and/or customs are truly consistent with Christian teachings. Thus, having this knowledge, its hearers could distinguish between those who are

"I buoni, ed rei insieme s'accordano in molte cose, per le quali non li conosceresti l'uno dall'altro (...) Ma pur in certe cose si divisano, in certe singularitadi (...) Prima dico c'ha singularità nel frutto; e quale è questo? Quando tu vedi l'uomo, che si guarda da'pecati mortali, vedi che sta in orazione, sta in frutto di penitenzia, cioè, che si confessa, rende l'altrui, ed altri buoni frutti; questi al postutto i rei non fanno; ma i rei, avvegnachè tu veggi che alcun'otta facian limosina, o digiunino, tuttavia se tu vedi che sieno carnali, lussuriosi, o cupidi, o micidiali, o ingannatori, o detrattori, e stare in peccato mortale, abbigli permali arbori verminosi. Simigliantemente se tu gli vedi con mala dottrina di peccati, o di resie, i quali non s'accordano con la dottrina di Cristo, abbigli costoro per mali arbori, avvegnachè questa resia e'non dicano palese, ma di celato, in occulto. E però per questo dovrebbe l'uomo essere istudioso di venire alle prediche, ove s'ammaestra la dottrina di Cristo; almeno non ci venisse l'uomo per altro se non che chi usa le prediche troppo bene conosce le parole, che tengono resia, e conosce il fondo loro, e sassene guardare, e difendere quando bisognasse. Ma gli altri, che non vengono alle prediche, como le conosceranno, come si difenderanno quando bisognerà? E però è di somma utilità la predica. Non è nullo che, vegnendo alla predica, non oda qualche parola utile, che gli fa molto pro. Dunque per la singularità di questi frutti, i buoni da'rei si conoscon bene, chi è savio". 
the true prophets/teachers (that in addition to spreading the word of Christ and the commandments of God, act according to them) from those who only impersonate them (who prophesize, but act otherwise). Preaching would enable the public to defend themselves against those who commit sin and who may influence their behaviour in a negative way. In addition, it would offer instruction on faith insofar as it would also enable the recognition of heretics through their words.

Taking together the introduction and the first part of the sermon, in addition to the distinction between good and bad masters, these teachers can still be classified as those who instruct by speech and those who teach by action (although speech is also an action). The identification on the basis of this latter characterization would be more difficult and it would be precisely preaching that would teach one to identify them and thus make it possible to defend oneself against the wicked masters. Besides exposing this, by highlighting the importance of good teachers what Giordano also secured his own authority as a good prophet/teacher. The preacher would correspond to that second type of prophet listed: he who speaks of things of the present time that are unknown to others (i.e., right modes of action). Thus he exalted his own role as a preacher and sets himself up as a model of behaviour: "One cannot say how useful is a good teacher and how necessary and useful he is" (Giordano, Prediche del beato fra I 171). ${ }^{57}$ In these terms, therefore, preaching was a true school on moral and faith in which the preacher was the master teacher.

Having stressed the informative-educational feature of preaching, both in terms of morality and faith, there is yet another sermon by Giordano da Pisa, from the same year 1304, which presents some important considerations about the preaching activity. Twenty days after the first sermon considered here, one late Sunday afternoon, 9 August, again in Santa Maria Novella, Giordano once more highlighted the role of preaching (Giordano, Prediche del beato fra I 245). Following the Dominican Lectionary (Ordo, Ordinarium 186), that day the friar preached about the gospel passage in Luke 18, 10, which states: "Two men went up into the temple to pray; the one a Pharisee, and the other a publican". According to the parable told by Christ, before God the Pharisee exalted himself, claiming not to be like other men -thieves, unrighteous and adulterers- nor as the publican who also prayed there; the publican, on the other hand, humbled himself, recognized himself as a sinner, and pleaded for divine mercy. As a result of these two contrasting attitudes, according to the biblical text the Pharisee would later be humbled and the publican exalted, "For whosoever exalteth himself shall be humbled, and he that humbleth himself shall be exalted" (Luke 
18,14). The purpose of the sermon, therefore, was to show how Christ, through this parable, desired to remove man from his state of sin and pride, and to bring him into humility and penance (Giordano, Prediche del beato fra I 245).

Giordano divided his preaching in two parts, dedicating each one to the reasons why a man does not humble himself: nominally, by innocence and by the merit of a work. The first part was divided into three, each subsection being devoted to one reason why men consider themselves righteous when, in fact, they are in sin -even if they did not realize it (Giordano, Prediche del beato fra I 245). The first of these reasons would be ignorance, and in approaching it the friar offered an appreciation of the preaching activity. ${ }^{58} \mathrm{He}$, therefore, rhetorically asked: "And why does a man thus become ignorant?". And he himself answered: "Because they do not attend preaching, where the truth is taught; they do not read; they do not ask, they are not told (...) It is then necessary to demand to the wise the reason why man does not know, does not see himself well". Playing himself the role of this wise man, the preacher answered his own question by stating that truth would be recognized through Holy Scriptures. They would function as a mirror that allows the handler to see the imperfections of his own face and see himself as he really is; similarly, upon hearing the explanations of their words in a preaching, man would hear of his own defects and thus recognize himself as a sinner and become aware of his true condition: "Look then at the Divine Scripture and there you shall see thyself" (Giordano, Prediche del beato fra I 246-247, emphasis added).$^{59}$

Anticipating a possible objection by the public, Giordano made the following amendment, in which he once again highlighted the role of preaching as a pedagogical activity, emphasizing now its public character: "But you shall say: I cannot read. But you are not excused, brother, for you come to preaching, where it [the Holy Scripture] is preached and continually shown by the preachers" (Giordano, Prediche del beato fra I 247). ${ }^{60}$

58 It is interesting to note the insertion of the preaching motto in this sermon, whose thema bears the figure of the Pharisee, since Alain de Lille, at the beginning of his Summa de arte praedicatoria, quotes this same character as a counterexample of correct preaching. According to the theologian, those who preach with highly adorned words do their preaching like the Pharisees who, through it, would only have the purpose of widening their phylacteries and the fringes of their garments (Matthew 23, 5). And Alain continues: the preaching of the Pharisees "may be said to be suspicious" [“(...) potest dici suspiciosa (...)] (Alanus col. 112-113).

"E perchè diventa l'uomo così ignorante? Però che non vanno alle prediche, ove s'ammaestra la verità, no leggono, non domandono, non è loro detto (...) Ancora dee dimandare al savio, perchè l'uomo non conosce, né vede bene se stesso (...) Riguarda dunqque nella Divina Scrittura, ed ivi ti vedrai (...)".

60 "Or direstù: io non ci posso leggere: frate, non se'però scusato; e tu vieni alle prediche, ov'ella si dice; e mostra per li predicatori continuamente". 
The preaching eulogy then continued:

Above all thing, preaching is useful. Those who do not use it have problems, because here people gain the knowledge regarding sin, and are instructed in truth. Those who do not come remain in darkness and do not know it, do not know how to defend themselves against temptation. And the danger they are in is the greatest and it is impossible not to fall into severe sin he who does not attend preaching. And he said: I met those monks and religious men who almost never come to hear preaching and do not read. We found them in great sin and they did not believe to be in sin because the mind alone is not enough. Although the Scripture is an explanation of natural reason, yet our reason hides itself through sins, puts itself behind clouds, snow, and the stains of $\sin$. And so it is hidden, it does not see itself and it does not show the light in you. For two things we become blind: one by the concealment of reason; the other for not having faith (...) But you shall say: but I do have Faith; or am I not a Christian? I confess to you that you have Faith, but you have it very roughly, you do not have it particularly well, no; and therefore you fall into sins and do not even realize it. To use preaching is the best thing that can exist in order to know the mercies and the ways of evil and good. The usurers do not go to preaching; they are among themselves and give themselves reasons and do not see themselves committing sin. And [he] said: should I not have pride? And then ask me: so speak of piety. But they do not come here where one hears of the malice and severity of usury. So you can say: as regards this attending to preaching, I don't know if it really benefits me and it doesn't seem to cheer me up, not even seems to be in my memory. No, brother, this is not to be said. I say that if you use it, you cannot not cheer yourself up, whether you want it or not. Say, however, that it is not in your mind. At least when you are going to do sin and evil, and you come to it, then you will remember, you will not do it and you will say: that I don't want to do, for the friar said it was not good and said it was a sin. So it is a great good to use preaching: here you know your sins and their severity. By not using it one becomes ignorant, one does not know, one makes sins and it does not seem serious to him. And so they say that they are innocent, but in fact they are full of a lot of filth (...) And I found many people who when comes to confession say: I don't know what to say; I don't think I have sinned. Oh, how rude and blind! And he said: and then 
we question them, and find them in great and many sins. This is due to great ignorance; they do not seek them properly and do not think of them. So, to use preaching, this is one of the best things that can exist. Friar Giordano praised it very much, and many then cheered themselves up. Problems have those who do not attend preaching and blessed are those who go to them, even if they are in sin (...) But those who do not attend it remain in much darkness and much danger like that Pharisee who was unclean in sin, and he did not notice himself to be filthy. But God saw it perfectly (Giordano, Prediche del beato fra I 247-250). ${ }^{61}$

As can be observed, according to Giordano preaching is par excellence a pedagogical activity. It is a teaching action whose source material is truth as revealed

61 "Sopra tutte le cose la predica utile, guai a chi non le usa, perocchè quivi le persone hanno conoscimento del pecato, e sono ammaestrati della verità. Quelli, che non ci vengono, rimangono in tenebre, e non conoscono, e non si sanno difendere dalle tentazioni; ed il loro pericolo è sommo, ed è impossible che non caggia in gravi peccati chi le prediche non usa. E disse: io ho travati di cotali monacelli, e religiosi, che non vengono mais quasi a udire predica, e non leggono; noi gli avemo trovati im gravi peccati, e non si credono peccare, perrochè la mente per se non basta; chè avvegnachè la Scrittura sia uno spiegamento della ragione naturale, tuttavia la nostra ragione sì si oculta per li peccati; pongonlesi dinanzi le nuvole, e le nebbie, e le macchie di peccati; e cosi s'occulta, e non vede, e non mostra luce in te. Per due cose diventamo ciechi; l'una per lo appiamento della ragione; l'altra per non avere Fede (...) Or direstù: gia io ho ben Fede, or non sono io cristiano? Ben ti confesso tu hai Fede, ma tu l'hai troppo in grosso; ma tu non l'hai in particulare como si conviene, no; e però cadi ne'peccati, e non te ne pur addai. L'usare le prediche, questa è la migliore cosa, che possa essere per conoscere le mercede, e le vie del male, e del bene. Gli usurai non vanno alle prediche, stannosi pur tra loro, e dicono loro ragioni, e non para loro peccare. Che dice: or non ne debbo io avere prode? Or e'me ne prega; e parli cosi di pietà; ma e'non viene colà ove udirebbe dire la malizia, e le gravezza dell'usura. Or potresti già dire; questo venire ale prediche io non so che mi si giovi, e non pare che mi si appicchi, nè che mi stea a memoria. Non, frate, non dire; dico che, se tu ci userai, no potrà essere che non te sene appicchi, o voglia tu, o no. Pognamo che tuttavia non ti stea a mente; almeno quando tu venissi a fare il peccato, e l'male, e venisse al fatto, allora si te ne ricorderesti, e nol faresti, e'diresti: questo non volglio io fare; chè'l Frate disse che non era buono, e disse ch'era peccato. Sicchè troppo è sommo bene usare la prediche; ivi conosci i peccati tuoi, e la gravezza. Per no usare ciò la persona è ignorantem non conosce, fa i peccati, e no gli riputa grave. E però si reputano innocent, e di verità e sono pieni di molta sozzura (...) io ho trovati più, che quando si vengono a confessare dicono: io non so che mi dire, e non mi pare quasi avere peccato; oh come sono grossi, e ciechi! Chè diss'egli: e noi gli dimandiamo poi, e trovamili in gravi peccati, e in molti. Questo é per grande ignoranzia, e non si cercano bene, e non ne pensano. Dunque l'usare le prediche, questo è delle migliore cose, che possa essere, molto il lodò Frate Giordano, e molto ci si riscaldò suso. Guai a quelli, che non visitano le prediche, e beato quegli, che le visita, avvegnachè sia in peccato (...) Ma quelli, che non le visitano, rimangono in molta tenebria, e in molto pericolo come questo Fariseo, ch'era sozzo in peccati, e non gli parea essere sozzo; ma Iddeo ben lo vedea". 
by the explanation of Holy Scriptures. Thus, this conception agrees with that of all other authors analysed, since they affirm that preaching should be based on biblical texts and that it serves to illuminate actions. Moreover, indirectly Giordano also established himself as the teacher of this instruction, for it was he who as a preacher, that afternoon of 9 August 1304 and on several other occasions, ministered the truth. When he stated that the wise man must be demanded as to why man does not know himself and he himself has revealed the answer, he presented himself as having the wisdom about truth. The friar, as a teacher, would be imbued with authority and knowledge. In the specific case, according to Giordano, the ordinary man, by himself and as a result of original sin, would not possess the ability to know himself. Therefore, it is necessary to explain the Scripture: by learning about truth in a preaching, by contrast, a man would recognize that the traits in himself which he considers to be right are, in fact, defects that need adjustment; he would see himself as a sinner and would know how to properly confess to receive guidance on proper penance and thus be reconciled with God, salving his soul. Because of this indispensable process of truth's revelation and the consequent self-knowledge of one's corrupted and sinful nature, then it would follow the need for man to know the Scriptures in depth - read them, demand to the most learned on the doubts about it, and, especially in the case of the illiterate, listen to preaching.

As must be noted, as postulated by Alain de Lille, Humbert of Romans, and Jacobus of Fusignano, some aspects of preaching were in fact ensured by Giordano da Pisa in his own activity as a preacher in Florence in the early fourteenth century. The aspect of the public manifestation highlighted by Alain de Lille was somewhat present when the friar stated that through preaching even the illiterate could have access to the knowledge found in the books of the Bible. ${ }^{62}$ And since access to it was allowed and encouraged to all belonging to the Christian community, there would be no excuse for staying in what Giordano calls ignorance - not knowing about sins and truth and consequently executing sinful acts as if they were lawful actions. Second, the friar made it clear that preaching is a way of teaching men about faith. The preacher further emphasized that some, simply because they are Christians, believe that they have a proper made during a sermon preached on a Sunday, 20 October 1303. The friar said: "The preacher preaches one thing, that is, one voice and it is entirely in the ears of all the people; not in part, but all in each one. Thus, each one fully has that voice in it and is also one and the same. And see that it is in many places" ["Il predicatore predica una cosa, cioè una voce, ed è interamente negli orecchi di tutto il Popolo, non per parte, ma in catuno tutta; onde catuno hae ienamente quella você in sè, ed è purê una medesima, e vedi ch 'è in cotante luogora”"] (Giordano, Prediche Inedite del B. Giordano 104). 
Faith. However, as Giordano explained, since men possess it in a defective way, only the guidance provided by preaching and the preacher would be able to inform him that his faith is problematic and lacking adjustment -as well as, ultimately, to return man to a renewal of his life. In other words, the preacher informs the listener that he is a sinner, and with this information, the man has the possibility of abandoning sin and turning to God, thus salving his soul.

Moreover, about halfway through the last passage quoted, Giordano made it clear that his purpose through preaching was, at the same time, to form customs. What he wanted was to constitute a lifestyle, to establish beliefs that would form a set of norms that determine dualities to guide human life in society by establishing what must be considered as fair and unfair, as well as good and evil, desirable and undesirable, useful and useless. The man who attends preaching would acquire or develop the ability to form this set of notions in himself and would remember the advice given by the preacher on the verge of acting contrary and sinful to what was determined by him. Due to this reminiscence, one was expected to act according to the precepts issued by the preacher. In other words, through sermon the preacher intended to lead not only beliefs but also attitudes. By means of the individual direction and a rule of conscience, the purpose of preaching was to institute a social order as certain practice were performed and repeated by many individuals. By enduring over time and, therefore, forming morals, these practices would guide the values and actions of others, so that they would form norms widely shared as current by a society.

Thus, according to the ideas expressed by Giordano da Pisa in his preaching activity in early fourteenth-century Florence, preaching can be determined as an instruction on the precepts of faith, sins and truth according to Holy Scriptures, whose purpose is to reach salvation through the formation of custom, that is, ordination of wills and direction of actions.

\section{CONCLUSION}

Comparing all the definitions and comments on the preaching activity presented by the three Dominican Friars, it is noticeable that the instructive feature is common to their ideas and statements -as well as it was presented by Alain de Lille. This instruction, according to all of them, without exception, must first depart from and deal with Holy Scriptures, divine things, faith, and truth; but it must also deal with morals, customs, vices, and sins. Moreover, it must be noted that in relation to Alain's definition, taken as a paradigm for the study of mendicant preaching, all three friars have settled salvation as its ultimate goal -hence, an important innovation in 
the definition offered by the theologian of Lille. Thus, it is possible to affirm that preaching can be synthesized into the following concept: preaching is an instruction about the Holy Scriptures, divine things, faith and truth; as well as about morals/ customs, vices, and sins, whose goal is the salvation of its audience.

\section{BIBLIOGRAPHIC REFERENCES}

Affò, Ireneo. "Vita del Beato Giordano da Rivalto". Prediche Inedite del B. Giordano da Rivalto dell'Ordine de Predicatori recitate in Firenze dal 1302 al 1305. Giordano da Pisa. Ed. Enrico Narducci. Gaetano Romagnoli, 1867, pp. XI-XXVI.

Agambem, Giorgio. The Kingdom and the Glory: for a Theological Genealogy of Economy and Government (Homo Sacer II, 2). Stanford University Press, 2011.

Alves, Aléssio Alonso. Sermons, Preaching, and Liturgy: Practices, Research Methods, and the Case of Giordano da Pisa. Medieval Sermon Studies, vol. 62, no. 1, 2018, pp. 3-16. https://doi.org/10.1080/13660691.2018.1520965.

Anderson, Roger (ed.). Constructing the Medieval Sermon. Brepols, 2007. http:// dx.doi.org/10.1484/M.SERMO-EB.6.09070802050003050205080901.

Bataillon, Louis-Jean. "Approaches to the Study of Medieval Sermons". Leeds Studies in English, n.s. 11, 1980, pp. 19-35.

Berardini, Valentina. "Prédicateurs et Acteurs. À la reherche d'indices e performance dans le sermons de la fin du Moyen ge". Prédication et performance du XIIe au XVIe siècle, edited by Marie Bouhaïk-Gironès and Marie Anne Polo de Beaulieu, Classiques Garnier, 2013, pp. 79-90.

Bériou, Nicole. L'avènement des maîtres de la Parole: la prédication à Paris au XIIIe siècle. Vol. 1. Institut d'Études Augustiniennes, 1998.

---. "Un mode singulier d'éducation. La prédication aux derniers siècles du Moyen Age". Communications, no. 72, 2002, pp. 113-127. https://doi. org/10.3406/comm.2002.2100.

Bériou, Nicole and Franco Morenzoni. Prédication et Liturgie au Moyen Age. Brepols, 2008. http://dx.doi.org/10.1484/M.BHCMAEB.6.09070802050003050204030200.

Charland, Thomas-Marie. Artes Predicandi. Contribution a l'Histoire de la Rhétorique au Moyen Age. Insti. D’Études Médiévales, 1936.

Constable, Giles. "The Language of Preaching in the Twelfth Century". Viator, no. 25, 1994, pp. 131-52. https://doi.org/10.1484/J.VIATOR.2.301211.

Corbari, Eliana. Vernacular Theology: Dominican Sermons and Audience in Late Medieval Italy. PhD thesis, University of Bristol, 2008. 
D'Avray', David. The Preaching of the Friars: Sermons diffused from Paris before 1300. Oxford University Press, 1985.

---. "Method in Study of Medieval Sermons". Modern Questions about Medieval Sermon: essays on marriage, death, history and sanctity, organized by Nicole Bériou and David D'Avray, Centro italiano di studi sull'Alto Medioevo, 1994, pp. 3-29.

---. Medieval Marriage Sermons: Mass Communication in a Culture without Print. Oxford University Press, 2001. https://doi.org/10.1093/ acprof:oso/9780198208143.001.0001.

Delcorno, Carlo. Giordano da Pisa e l'antica predicazione volgare. Leo S. Olschki Editore, 1975.

---. "Medieval Preaching in Italy (1200-1500)". The Sermon, directed by Beverly Mayne Kienzle, Brepols, 2000, pp. 490-560.

Delcorno, Pietro. In the Mirror of the Prodigal Son: The Pastoral Uses of a Biblical Narrative (c. 1200-1550). Bookbuilders, 2015.

Ferzoco, George. "Preaching by thirteenth-century Italian hermits". Medieval Monastic Preaching, edited by Carolyn Muessig, Brill, 1998, pp. 145159. https://doi.org/10.1163/9789004247444_009.

Galletti, Alfredo. "Fra Giordano da Pisa: Predicatore del Secolo XIV". Giornale storico della letteratura italiana, XXXI, 1898, pp. 1-48, 193-243; XXXIII, 1899, pp. 193-264.

Hanska, Jussi. "Reconstructing the Mental Calendar of Medieval Preaching: A Method and Its Limitations in Analysis of Sunday Sermons". Preacher, Sermon and Audience in the Middle Ages, edited by Carolyn Muessig, Brill, 2002, pp. 293-315. https://doi.org/10.1163/9789047400226_014.

---. "Uidens Iesus Ciuitate fleuit super illam: The Lachrymae Christi Topos in Thirteenth-Century Sermon sermon literature". Constructing the Medieval Sermon, organized by Roger Anderson, Brepols, 2008, pp. 237251. https://doi.org/10.1484/M.SERMO-EB.3.3861.

Harper, Alexander. Patronage in the re-Christianized Landscape of Angevin Apulia: the Rebuilding of Luceria sarracenorum into Civitas Sanctae Mariae. PhD Tesis, University of Toronto, 2014.

Iannella, Cecilia. "Predicazione Domenicana ed Etica Urbana tra Due e Trecento". Predicazione e società nel medioevo: riflessione etica, valori e modelli di comportamento, organized by Laura Gaffuri and Riccardo Quinto, Centro studi Antoniani, 2002, pp. 171-185. www.academia.edu/30577679/ Predicazione_domenicana_ed_etica_urbana_tra_Due_e_Trecento_in_ Predicazione_e_società_nel_Medioevo_riflessione_etica_valori_e modelli_di_comportamento_a_cura_di_Laura_Gaffuri_Riccardo_- 
Quinto_Padova_Centro_Studi_antoniani_2002_pp_171_185. Acess: 6 November 2020.

---. Giordano da Pisa. Ética Urbana e Forme della Società. Edizione ETS, 1999. Kienzle, Beverly Mayne (dir.). The Sermon. Brepols, 2000.

Lefort, Claude. Democracy and Political Theory. University of Minnesota Press, 1988.

Muessig, Carolyn (ed.). Medieval Monastic Preaching. Brill, 1998. https://doi. org/10.1163/9789004247444.

---. Preacher, Sermon and Audience in the Middle Ages. Brill, 2002. https://doi. org/10.1163/9789047400226.

Mulchahey, M. Michèle. First the Bow is Bent in Study: Dominican Education before 1350. Pontifical Institute of Medieval Studies, 1998.

Palermo, Massimo. "Serialità e iterazione in Giordano da Pisa e Bernardino da Siena". Lingua e Stile, no. 51, dicembre 2016, pp. 169-193. www. academia.edu/31030751/Serialità_e_iterazione_in_Giordano_da_ Pisa_e_Bernardino_da_Siena. Access: $\overline{6}$ November 2020.

Rivers, Kimberly A. Preaching the Memory of Virtue and Vice. Memory, Images, and Preaching in the Late Middle Ages. Brepols, 2010. https://doi. org/10.1484/M.SERMO-EB.5.106311.

Stoop, Patricia. "The Writing Sisters of Jericho: Authors or Copyists?". Constructing the Medieval Sermon, edited by Roger Anderson, Brepols, 2007, pp. 275-308. https://doi.org/10.1484/M.SERMO-EB.3.3863.

Swan, Mary. "Constructing Preacher and Audience in Old English Homilies". Constructing the Medieval Sermon, edited by Roger Anderson, Brepols, 2007, pp. 177-188. https://doi.org/10.1484/M.SERMO-EB.3.3857.

Thayer, Anne T. "Medieval Sermon Studies since The Sermon: A Deepening and Broadening Field". Medieval Sermon Studies, vol. 58, 2014, pp. 10-27. https://doi.org/10.1179/1366069114Z.00000000018.

Thompson, Augustine. Cities of God. The Religion of the Italian Communes. The Pennsylvania State University Press, 2005.

---. "From Texts to Preaching: Retrieving the Medieval Sermon as an Event". Preacher, Sermon and Audience in the Middle Ages, edited by Carolyn Muessig, Brill, 2002, pp. 13- 40. https://doi. org/10.1163/9789047400226_003.

Tugwell, Simon. Early Dominicans: Selected Writings. Paulist Press, 1982.

---. Ways of Imperfection: An Exploration of Christian Spirituality. Templegate Publishers, 1985.

Wenzel, Siegfried. The Art of Preaching: Five Medieval Texts \& Translations. The Catholic University of America Press, 2013. 
---. Medieval Ars Praedicandi: a Synthesis of Scholastic Sermon Structure. University of Toronto Press, 2015.

Zink, Michael. La prédication em langue romane avant 1300. Honoré Champion, 1976.

\section{Primary Sources}

Alanus de Insulis. Summa de arte praedicatoria. Patrologia Latina, tomo 210. Garnier Fratres, 1864.

Aristotle. Metaphysics. 23 vol. Translated by Hugh Tredennick. Cambridge, MA, HarvardUniversityPress;London,WilliamHeinemannLtd.1933,1989.www. perseus.tufts.edu/hopper/text?doc $=$ Perseus\%3atext\%3a1999.01.0052. Access: 10 April 2020.

Aristotle, and Joe Sachs. Aristotle's Physics: A Guided Study. Rutgers University Press, 1998.

Bonaini, Francesco. Chronica antiqua conventus Sanctae Catharinae de Pisis. Archivio storico italiano, I serie, tomo 6, parte II. GIO Pietro Vieusseux, 1845. pp. 399-593.

Cicero. De Fato. Ed. C. F. W. Müller. Teubner, 1915.

Giordano da Pisa. Prediche del Beato F. Giordano da Rivalto dell'Ordine de' Predicatori. Stamperia di Pietro Gaetano Viviani, 1739.

---. Prediche del beato fra Giordano da Rivalto dell'Ordine dei Predicatori recitate in Firenze dal MCCIII al MCCCVI ed ora per la prima volta publicate. Tomo I. Magheri, 1831.

---. Prediche del beato fra Giordano da Rivalto dell'Ordine dei Predicatori recitate in Firenze dal MCCIII al MCCCVI ed ora per la prima volta publicate. Tomo II. Magheri, 1831.

---. Prediche Inedite del B. Giordano da Rivalto dell'Ordine de Predicatori recitate in Firenze dal 1302 al 1305. Ed. Enrico Narducci. Gaetano Romagnoli, 1867.

Humbert de Romanis. De eruditione praedicatorum. Ex tipographia Sebastiani à Cormellas, 1607.

Jacobus de Fusignano. "Libellus Artis Predicatorie". The Art of Preaching: Five Medieval Texts \& Translations. Wenzel, Siefried. The Catholic University of America Press, 2013. pp. 9-96.

Ordo Praedicatorum. Missale s[ecundu]m consuetudinem fratrum predicatorum: cum omnibus additionibus tam ad conuentualem $\mathrm{q}[\mathrm{uam}]$ ad priuatam missam pertinentibus. Andreas Torresanus, 1496.

---. Ordinarium Juxta Ritum Sacri Ordinis Fratrum Praedicatorum. Ed. Ludovici Theissiling. Apud Collegium Angelicum, 1921. 